\title{
Leguminous Cover Crop Astragalus sinicus Enhances Grain Yields and Nitrogen Use Efficiency through Increased Tillering in an Intensive Double-Cropping Rice System in Southern China
}

\author{
Jiangwen Nie ${ }^{1,3}$, Lixia Yi ${ }^{1}$, Heshui Xu ${ }^{2}$, Zhangyong Liu ${ }^{1}$, Zhaohai Zeng ${ }^{3}$, Paul Dijkstra ${ }^{4}$, \\ George W. Koch ${ }^{4}$, Bruce A. Hungate ${ }^{4}$ and Bo Zhu ${ }^{1, *}$ \\ 1 Hubei Collaborative Innovation Center for Grain Industry, Yangtze University, Jingzhou 434025, China; \\ b20183010007@cau.edu.cn (J.N.); 501068@yangtzeu.edu.cn (L.Y.); lyz1331@hotmail.com (Z.L.) \\ 2 Shanghai Academy of Agricultural Sciences, Shanghai 201403, China; xhsh0112@outlook.com \\ 3 College of Agronomy and Biotechnology, China Agricultural University, Beijing 100193, China; \\ zengzhaohai@cau.edu.cn \\ 4 Center for Ecosystem Science and Society, Northern Arizona University, Flagstaff, AZ 86011, USA; \\ Paul.Dijkstra@nau.edu (P.D.); George.Koch@nau.edu (G.W.K.); Bruce.Hungate@nau.edu (B.A.H.) \\ * Correspondence: 501045@yangtzeu.edu.cn; Tel.: +86-0716-8066314; Fax: +86-0716-8066314
}

Received: 24 July 2019; Accepted: 10 September 2019; Published: 16 September 2019

\begin{abstract}
Chinese milk vetch (Astragalus sinicus L., vetch), a leguminous winter cover crop, has been widely adopted by farmers in southern China to boost yield of the succeeding rice crop. However, the effects of vetch on rice grain yield and nitrogen $(\mathrm{N})$ use efficiency have not yet been well studied in the intensive double-cropped rice cropping systems. To fill this gap, we conducted a three-year field experiment to evaluate the impacts of the vetch crop on yields and $\mathrm{N}$ use efficiency in the subsequent early and late rice seasons. With moderate $\mathrm{N}$ input (100 $\mathrm{kg} \mathrm{N} \mathrm{ha}^{-1}$ for each rice crop), vetch cover significantly increased grain yields by $7.3-13.4 \%$ for early rice, by $8.2-10.4 \%$ for late rice, and by $8.6-11.5 \%$ for total annual rice production when compared with winter fallow. When rice crops received an $\mathrm{N}$ input of $200 \mathrm{~kg} \mathrm{~N}^{-1}$, vetch cover increased grain yields by $5.9-18.4 \%$ for early rice, by $3.8-10.1 \%$ for late rice, and by $6.2-11.3 \%$ for annual rice production. Moreover, comparable grain yields (11.9 vs. $12.0 \mathrm{Mg} \mathrm{ha}^{-1}$ for annual rice production) were observed between vetch cover with moderate $\mathrm{N}$ and fallow with added $\mathrm{N}$ fertilizer. Yield components analysis indicated that the increased tillering number was the main factor for the enhanced grain yields by vetch cover. Vetch cover with moderate and higher $\mathrm{N}$ input resulted in higher agronomic $\mathrm{N}$ use efficiency and applied $\mathrm{N}$ recovery efficiency compared with the fallow treatments. Here, our results showed that vetch as a winter cover crop can be combined with reduced $\mathrm{N}$ fertilizer input while maintaining high grain yields, thus gaining a more sustainable rice production system.
\end{abstract}

Keywords: leguminous cover crop; vetch; double cropping; grain yield; $N$ uptake; $N$ use efficiency; rice

\section{Introduction}

Rice (Oryza sativa L.) is one of the most important food crops in China, with a planted area of 30 million ha and a gross grain production of 206 million tons in 2014. Chemical nitrogen (N) fertilizer, as high as $193 \mathrm{~kg} \mathrm{~N} \mathrm{ha}^{-1}$, is regularly applied for each cropping season, with less than $36 \%$ of it recovered by the rice crop [1]. Sustainable rice production in this region is hampered by excessive $\mathrm{N}$ fertilizer application since: (1) rice grain yield increase is lower than $\mathrm{N}$ rate increase, leading to decreased partial factor productivity from applied $\mathrm{N}$ [2], (2) high $\mathrm{N}$ fertilizer input increases 
farmers' costs, and (3) decreased $\mathrm{N}$ use efficiency may be associated with high risk of $\mathrm{N}$ losses into the environment, resulting in environmental problems, such as nitrogen leaching [3], $\mathrm{N}_{2} \mathrm{O}$ and $\mathrm{NH}_{3}$ emissions, and subsequent high atmospheric $\mathrm{N}$ deposition rates [4].

Some strategies have been developed to balance the $\mathrm{N}$ effects on crop yield and environmental risks [1]. Improved $\mathrm{N}$ use efficiency can be achieved by using slow-release sulfur- or polymer-coated $\mathrm{N}$ fertilizer [5], multisplit topdressing, deep placement of fertilizer, and integrated soil-crop management [6]. These management technologies were introduced to help to enhance crop $\mathrm{N}$ uptake and reduce $\mathrm{N}$ losses into the environment. However, most of these fertilizer products or fertilizer management strategies require high cost or additional labor input, which limit their adaptation by farmers.

Biologically fixed $\mathrm{N}$ may be an alternative, low-cost $\mathrm{N}$ source for farmers in China. Cover crops are commonly sown during the fallow period and can be used as an effective tool to improve $\mathrm{N}$ management in annual crop rotations [7]. Nonleguminous cover crops such as turnip rape (Brassica rapa) and Italian ryegrass (Lolium multiflorum Lam.) have been used to intercept postharvest surplus $\mathrm{N}$ that would otherwise be leached into rivers and groundwater [8,9]. Leguminous cover crops such as Chinese milk vetch (Astragalus sinicus L.), crimson clover (Trifolium incarnatum L.), and purple vetch (Vicia benghalensis $\mathrm{L}$.) can fix atmospheric $\mathrm{N}_{2}$, reduce nitrate leaching, and increase soil $\mathrm{N}$ availability for the succeeding main crops [10-12], thus decreasing the reliance on synthetic fertilizer $\mathrm{N}$ and reducing the associated costs and environmental risks.

Chinese milk vetch is a widely used leguminous cover crop in the double-cropping rice systems in southern China. It is usually broadcast into the paddy field approximately two weeks before the late rice harvest and incorporated into the soil at blooming stage, about one or two weeks before the early season rice planting. It is hypothesized that there should be a synergistic interaction between vetch incorporation and chemical fertilizer $\mathrm{N}$ on rice grain yield and $\mathrm{N}$ use efficiency. However, the evidence is limited. Knowledge of the interaction between milk vetch incorporation and chemical fertilizer $\mathrm{N}$ is important for the optimal use of both cover crop and chemical fertilizers.

In the present study, we measured rice grain yield and $\mathrm{N}$ use efficiency for three years in a field experiment. The study has two main objectives: to evaluate the combined effects of vetch as a leguminous winter cover crop and fertilizer $N$ application rate on (1) rice grain yields and (2) $N$ use efficiency of the double-cropping rice system.

\section{Materials and Methods}

\subsection{Experimental Site}

A three-year field experiment (2015 to 2017) was conducted in a farmer's field in Huarong County $\left(29^{\circ} 52^{\prime} \mathrm{N}, 12^{\circ} 55^{\prime} \mathrm{E}\right)$ in Dongting Lake Plain, Hunan province, China. The climate in this region is subtropical, monsoonal, and humid. The most widely practiced cropping system consists of growing two rice crops followed by winter fallow or a cover crop. The soil was a clay loam that contained $24.7 \%$ sand, $61.1 \%$ silt, and $14.2 \%$ clay, and $\mathrm{pH}\left(\mathrm{H}_{2} \mathrm{O}\right)$ was 6.1 . Soil organic matter was $3.02 \%$, while soil total $\mathrm{N}$ was $0.12 \%$; Olsen extractable phosphorus was $12.7 \mathrm{mg} \mathrm{kg}^{-1}$ and available potassium was $107.5 \mathrm{mg} \mathrm{kg}^{-1}$ soil.

\subsection{Treatments and Crop Management}

The experimental treatments were: (1) winter fallow without $\mathrm{N}$ application during the main crop rice season as a control $\left(\mathrm{FN}_{0}\right)$; (2) winter fallow and a moderate $100 \mathrm{~kg} \mathrm{~N} \mathrm{ha}^{-1}$ for each rice crop $\left(\mathrm{FN}_{100}\right)$; (3) vetch cover crop in winter and $100 \mathrm{~kg} \mathrm{~N} \mathrm{ha}^{-1}$ for each rice crop $\left(\mathrm{MN}_{100}\right)$; (4) winter fallow and $200 \mathrm{~kg} \mathrm{~N} \mathrm{ha}^{-1}$ input for each rice crop $\left(\mathrm{FN}_{200}\right)$, and (5) vetch cover cropping in winter and $200 \mathrm{~kg} \mathrm{~N} \mathrm{ha}^{-1}$ for each rice crop $\left(\mathrm{MN}_{200}\right)$. The experimental design was a completely randomized block design with three replications. Blocks were separated by $1 \mathrm{~m}$ wide irrigation ditches and each treatment was randomly placed in $5 \mathrm{~m} \times 6 \mathrm{~m}$ plots within each block. Plots were separated by $0.5 \mathrm{~m}$ 
wide ridges covered with plastic film to avoid water and nutrients leaking. Treatments were assigned to the same experimental plots for three years.

Vetch seeds (cv. Xiangfei 3) were hand broadcast approximately 15 days before late rice harvest in early October. The vetch received no fertilizer during the winter growing season. The aboveground biomass of the vetch was incorporated into the soil at the blooming stage by plowing and puddling approximately 10 days before early rice planting. In the winter fallow plots, the soil was bare without straw or grass cover (Figure 1).
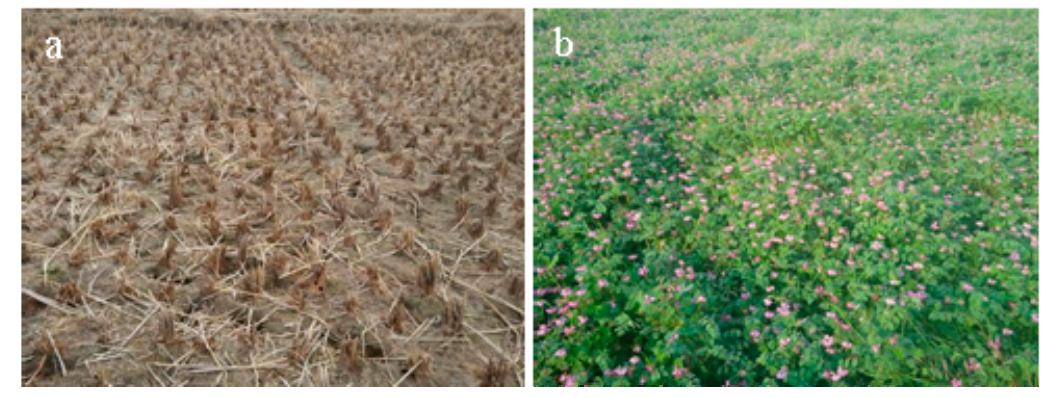

Figure 1. Planting patterns of the winter fallow (a) and the winter cover cropping with milk vetch (b) in a double-rice cropping system.

For the early rice, seedlings (cv. Luliangyou 996, $30 \mathrm{~d}$ old, hybrid cultivar) were planted at a spacing of $15 \mathrm{~cm} \times 20 \mathrm{~cm}$ with 2-3 plants per hill after field preparation and basal fertilization in late April and harvested in middle July. For the late rice, seedlings (cv. Yueyou 712, $30 \mathrm{~d}$ old, hybrid cultivar) were transplanted after early rice harvest and soil preparation, and harvested in late October. In each year, both early and late rice seasons received a basal fertilizer application in the form of $75 \mathrm{~kg} \mathrm{ha}^{-1}$ $\mathrm{P}_{2} \mathrm{O}_{5}$ (calcium super phosphate), $100 \mathrm{~kg} \mathrm{ha}^{-1} \mathrm{~K}_{2} \mathrm{O}$ (potassium chloride), and $70 \% \mathrm{~N}$ (urea or urea plus vetch residue in vetch plots), with the remaining $\mathrm{N}$ applied as top dressing at the tillering stage for both early and late rice seasons. For plots with vetch cover, basal $\mathrm{N}$ application in the early rice crop was reduced by the estimated $\mathrm{N}$ content in the vetch aboveground biomass residue. The field was flooded after early rice and late rice transplanting, and a floodwater depth of $3-5 \mathrm{~cm}$ was maintained until 10 days before maturity except that the water was drained at maximum tillering stage to reduce unproductive tillers. Herbicides and pesticides were used to avoid yield loss according to the actual demands. All plots received a similar field management for irrigation and crop protection during rice growth season.

\subsection{Sample Collection and Analysis}

Rice grain yield was determined at maturity by randomly harvesting two $4 \mathrm{~m}^{2}$ areas from each plot, while six representative hills of rice plants were collected to measure yield components and $\mathrm{N}$ uptake. Plants were separated into leaves, stems, and panicles. The dry weight of straw and grain was measured after oven drying at $75^{\circ} \mathrm{C}$ to constant weight. Yield components included number of panicles $\mathrm{m}^{-2}$, number of spikelets panicle ${ }^{-1}$, grain-filling percentage, and 1000 grains weight. Rice plant sample and vetch plant sample were weighed fresh, dried at $60^{\circ} \mathrm{C}$ to a constant weight. Tissue $\mathrm{N}$ concentration was determined by micro-Kjeldahl [13] and used to calculate total $\mathrm{N}$ uptake. Applied $\mathrm{N}$ recovery efficiency $\left(\mathrm{RE}_{\mathrm{N}}\right)$ and agronomic $\mathrm{N}$ use efficiency $\left(\mathrm{AE}_{\mathrm{N}}\right)$ were calculated following $\mathrm{Xu}$ et al. [14] as:

$$
\mathrm{RE}_{\mathrm{N}}=\frac{N F-N 0}{\text { Applied } N} \times 100
$$


where $N_{F}$ and $N_{0}$ are plant total $\mathrm{N}$ content $\left(\mathrm{kg} \mathrm{N} \mathrm{ha}^{-1}\right)$ of $\mathrm{N}$ addition treatments and unfertilized control, respectively, and Applied $N$ is the amount of $\mathrm{N}$ from urea and vetch.

$$
\mathrm{AE}_{\mathrm{N}}=\frac{G F-G 0}{\text { Applied } N} \times 100
$$

where $G_{F}$ and $G_{0}$ are grain yield $\left(\mathrm{kg} \mathrm{ha}^{-1}\right)$ of $\mathrm{N}$ addition treatments and unfertilized control, respectively.

\subsection{Statistical Analyses}

Data were analyzed using analysis of variance (SAS Institute, 2003) and means of rice grain yields, yield components, $\mathrm{N}$ uptake, and $\mathrm{N}$ use efficiency were compared based on the least significant difference (LSD) test at the 0.05 probability level.

\section{Results}

\subsection{Grain Yield and Yield Components}

Rice grain yield of the early rice, late rice, and annual rice production were significantly affected by year and treatment (Table 1). The interaction effect of year and treatment was significant for the early rice crop, but not significant for late rice and annual production. Vetch cover stimulated grain yield for the succeeding early and late rice compared with fallow at the same $\mathrm{N}$ application dose.

Compared with $100 \mathrm{~kg} \mathrm{ha}^{-1}$ chemical $\mathrm{N}$ fertilizer addition, vetch cover increased grain yields by $7.3-13.4 \%$ for early rice, by $8.2-10.4 \%$ for late rice, and by $8.6-11.5 \%$ for the total annual production (Table 2). This was similar for the $200 \mathrm{~kg} \mathrm{~N} \mathrm{ha}^{-1}$ treatments: $5.9-18.4 \%$ for early rice, $3.8-10.1 \%$ for late rice, and $6.2-11.3 \%$ for the total annual production higher with vetch cover than with winter fallow. With the exception of the late rice season in the year 2015, all differences between vetch and fallow were significant within the same $\mathrm{N}$ addition dose $(p<0.05)$.

Table 1. Analysis of variance ( $F$ values) for grain yield, total $\mathrm{N}$ uptake, agronomic $\mathrm{N}$ use efficiency $\left(A E_{N}\right)$, and fertilizer $N$ recovery efficiency $\left(R_{N}\right)$ of the early rice, late rice, and annual cycle rice in 2015, 2016, and 2017 in Huarong County.

\begin{tabular}{|c|c|c|c|c|c|c|c|c|c|c|c|c|}
\hline \multirow{2}{*}{$\begin{array}{l}\text { Source of } \\
\text { Variation }\end{array}$} & \multicolumn{4}{|c|}{ Early Rice } & \multicolumn{4}{|c|}{ Late Rice } & \multicolumn{4}{|c|}{ Annual Cycle Rice } \\
\hline & $\begin{array}{l}\text { Grain } \\
\text { Yield }\end{array}$ & $\begin{array}{l}\text { Total N } \\
\text { Uptake }\end{array}$ & $\mathrm{AE}_{\mathrm{N}}$ & $\mathrm{RE}_{\mathrm{N}}$ & $\begin{array}{l}\text { Grain } \\
\text { Yield }\end{array}$ & $\begin{array}{l}\text { Total N } \\
\text { Uptake }\end{array}$ & $\mathrm{AE}_{\mathrm{N}}$ & $\mathrm{RE}_{\mathbf{N}}$ & $\begin{array}{l}\text { Grain } \\
\text { Yield }\end{array}$ & $\begin{array}{l}\text { Total N } \\
\text { Uptake }\end{array}$ & $\mathrm{AE}_{\mathbf{N}}$ & $\mathrm{RE}_{\mathbf{N}}$ \\
\hline Treatment (T) & $359.8 * *$ & $144.8^{* *}$ & $78.0 * *$ & $21.3^{* *}$ & 89.0 ** & $92.0 * *$ & $5.1 * *$ & $4.7 *$ & $272.8^{* *}$ & $164.0 * *$ & $21.8^{* *}$ & $14.9 * *$ \\
\hline $\mathrm{Y} \times \mathrm{T}$ & $4.3^{* *}$ & $5.0^{* *}$ & NS & NS & NS & NS & NS & NS & NS & $4.0 * *$ & NS & NS \\
\hline
\end{tabular}

Table 2. Grain yields for the early rice, late rice, and annual rice cycle in the years 2015-2017 influenced by vetch covering.

\begin{tabular}{|c|c|c|c|c|c|c|c|c|c|}
\hline \multirow[b]{2}{*}{ Treatment } & \multicolumn{3}{|c|}{2015} & \multicolumn{3}{|c|}{2016} & \multicolumn{3}{|c|}{2017} \\
\hline & $\begin{array}{l}\text { Early Rice } \\
\left(\mathrm{Mg} \mathrm{ha}^{-1}\right)\end{array}$ & $\begin{array}{l}\text { Late Rice } \\
\left(\mathrm{Mg} \mathrm{ha}^{-1}\right)\end{array}$ & $\begin{array}{c}\text { Annual Rice } \\
\text { Cycle }^{\mathrm{a}} \\
\left(\mathrm{Mg} \mathrm{ha}^{-1}\right)\end{array}$ & $\begin{array}{l}\text { Early Rice } \\
\left(\mathrm{Mg} \mathrm{ha}^{-1}\right)\end{array}$ & $\begin{array}{l}\text { Late Rice } \\
\left(\mathrm{Mg} \mathrm{ha}^{-1}\right)\end{array}$ & $\begin{array}{c}\text { Annual Rice } \\
\text { Cycle } \\
\left(\mathrm{Mg} \mathrm{ha}^{-1}\right)\end{array}$ & $\begin{array}{l}\text { Early Rice } \\
\left(\mathrm{Mg} \mathrm{ha}^{-1}\right)\end{array}$ & $\begin{array}{c}\text { Late Rice } \\
\left(\mathrm{Mg} \mathrm{ha}^{-1}\right)\end{array}$ & $\begin{array}{c}\text { Annual Rice } \\
\text { Cycle } \\
\left(\mathrm{Mg} \mathrm{ha}^{-1}\right)\end{array}$ \\
\hline $\mathrm{FN}_{0}$ & $4.90 \mathrm{e}$ & $4.52 \mathrm{~d}$ & $9.42 \mathrm{~d}$ & $4.34 \mathrm{~d}$ & $4.25 \mathrm{~d}$ & $8.59 \mathrm{~d}$ & $3.96 \mathrm{~d}$ & $5.24 \mathrm{~d}$ & $9.19 \mathrm{~d}$ \\
\hline $\mathrm{FN}_{100}$ & $6.26 \mathrm{~d}$ & $5.06 \mathrm{c}$ & $11.32 \mathrm{c}$ & $5.30 \mathrm{c}$ & $4.64 \mathrm{c}$ & $9.94 \mathrm{c}$ & $5.09 \mathrm{c}$ & $6.07 \mathrm{c}$ & $11.16 \mathrm{c}$ \\
\hline $\mathrm{MN}_{100}$ & $6.72 \mathrm{~b}$ & $5.58 \mathrm{~b}$ & $12.29 \mathrm{~b}$ & $6.02 \mathrm{~b}$ & $5.021 \mathrm{~b}$ & $11.03 \mathrm{~b}$ & $5.74 \mathrm{~b}$ & $6.70 \mathrm{~b}$ & $12.44 \mathrm{~b}$ \\
\hline $\mathrm{FN}_{200}$ & $6.38 \mathrm{c}$ & $5.92 \mathrm{a}$ & $12.31 \mathrm{~b}$ & $5.83 \mathrm{~b}$ & $5.17 \mathrm{~b}$ & $11.00 \mathrm{~b}$ & $5.81 \mathrm{~b}$ & $6.91 \mathrm{~b}$ & $12.72 \mathrm{~b}$ \\
\hline $\mathrm{MN}_{200}$ & $7.56 \mathrm{a}$ & $6.15 \mathrm{a}$ & $13.70 \mathrm{a}$ & $6.51 \mathrm{a}$ & $5.69 \mathrm{a}$ & $12.20 \mathrm{a}$ & $6.15 \mathrm{a}$ & $7.35 \mathrm{a}$ & $13.50 \mathrm{a}$ \\
\hline
\end{tabular}

Note: Different letters in the same column mean there is a significant difference at the 0.05 level (LSD). The data shown in the panels are averages of the three replications for individual treatments. ${ }^{\text {a }}$ The grain yield for annual rice cycle is the sum of the early and late rice grain yields from the same plot within a year.

Yield components analysis indicated (Table 3) that rice grain yield increases associated with vetch cover were mostly the result of the increased panicle $\mathrm{m}^{-2}$ number, while the other three yield 
components, spikelets panicle ${ }^{-1}$, grain filling, and grain weight, were not significantly affected by treatments. Treatments with vetch cover showed higher panicle numbers for early rice in all of the years when compared with those with fallow. For panicle numbers of late rice, vetch cover increased panicle numbers compared to fallow at $100 \mathrm{~kg} \mathrm{~N} \mathrm{ha}^{-1}$ in three years, while increased panicle numbers were observed only in 2017 for the $200 \mathrm{~kg} \mathrm{~N} \mathrm{ha}^{-1}$ (Table 3).

Table 3. Yield components for the early rice and late rice in the years 2015-2017 influenced by vetch.

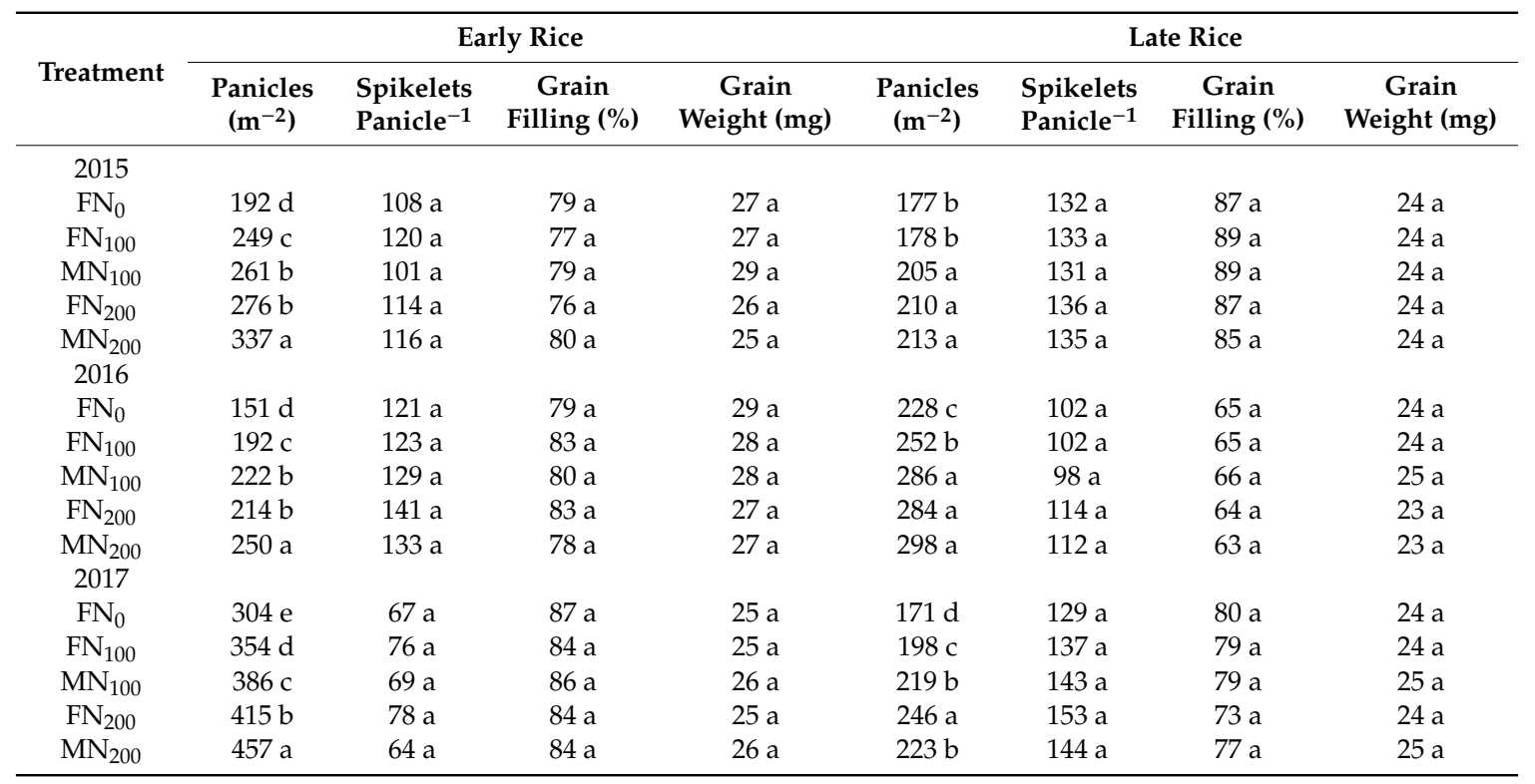

Note: Different letters in the same column in the same year mean there is a significant difference at the 0.05 level (LSD).

\subsection{N Uptake}

Year and treatment significantly affected total $\mathrm{N}$ uptake for the early and late rice crops and annual rice production. The interaction effect of year and treatment was significant for early rice and annual production, but not significant for late rice (Table 1).

The $\mathrm{N}$ uptake by early rice and late rice and annual $\mathrm{N}$ uptake increased significantly in response to $\mathrm{N}$ fertilizer (Figure 2). Consistent with the positive effect of vetch cover on grain yields, $\mathrm{N}$ uptake by rice plants was also significantly higher in the vetch treatments than in the fallow treatments (Figure 2). At $100 \mathrm{~kg} \mathrm{~N} \mathrm{ha}^{-1}$, vetch cover increased $\mathrm{N}$ uptake by $8.3-18.1 \%$ for early rice, by $6.0-8.8 \%$ for late rice, and by $7.1-13.2 \%$ for annual $\mathrm{N}$ uptake. At $200 \mathrm{~kg} \mathrm{~N} \mathrm{ha}^{-1}$, vetch cover enhanced $\mathrm{N}$ uptake by $9.2-26.6 \%$ for early rice, by $9.5-13.2 \%$ for late rice, and by $9.3-18.1 \%$ for annual $\mathrm{N}$ uptake (Figure 2).

\subsection{N Use Efficiency}

Both year and treatment had significant effects on $A E_{N}$ and $R E_{N}$ for early rice, late rice, and annual rice production, whereas the interaction between year and treatment on $\mathrm{AE}_{\mathrm{N}}$ and $\mathrm{RE}_{\mathrm{N}}$ was not significant (Table 1).

During the three-year study, $\mathrm{AE}_{\mathrm{N}}$ exhibited the same trend across treatments for early rice, late rice, and annual cycle rice crops (Figure 3). For the same $\mathrm{N}$ dose, treatments with the vetch cover demonstrated significantly greater $\mathrm{AE}_{\mathrm{N}}$ values than corresponding fallow treatments for early rice, late rice, and annual rice production $(p<0.05)$, with the exception of the late rice season in the years 2016 and 2017 (Figure 3). 

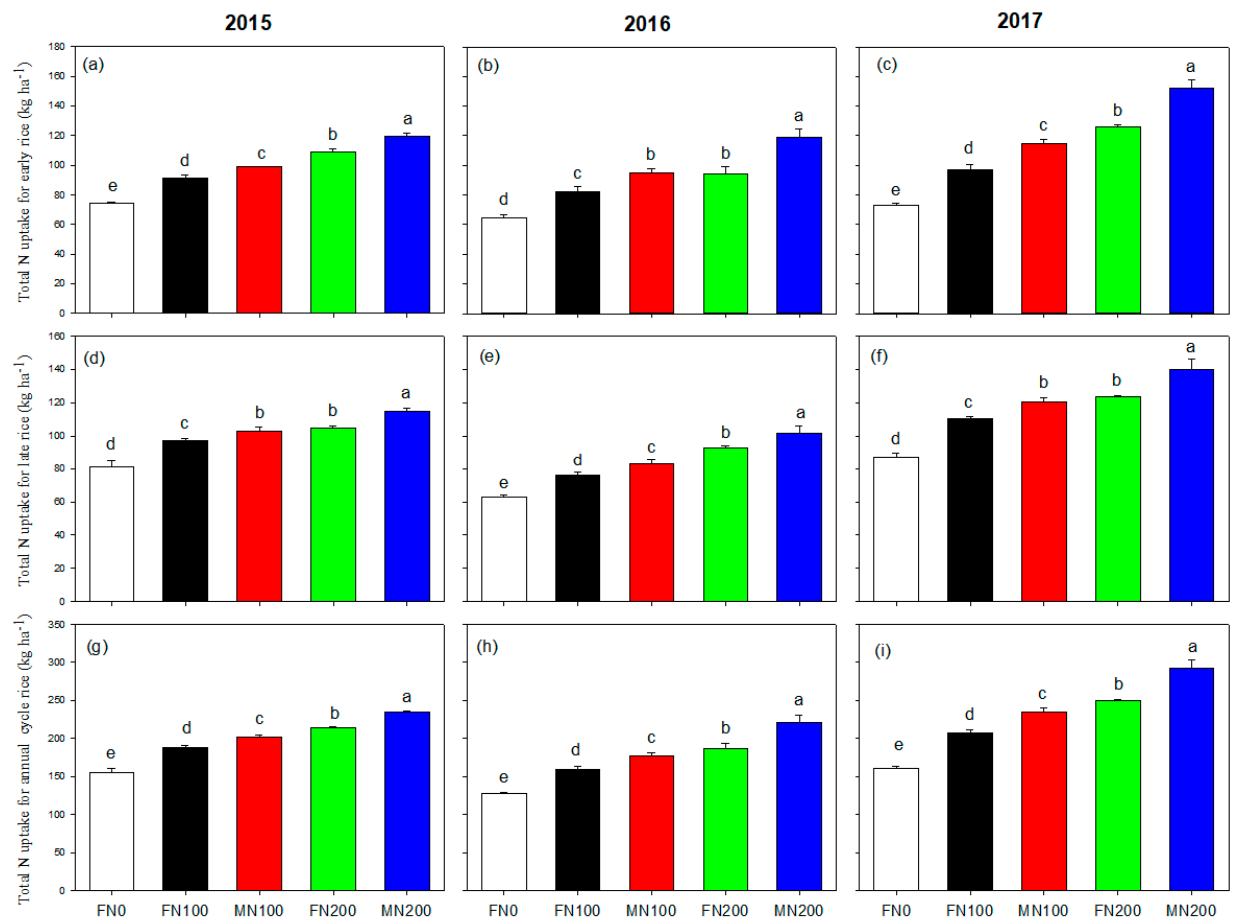

Figure 2. Total $N$ uptake for early $(\mathbf{a}-\mathbf{c})$, late $(\mathbf{d}-\mathbf{f})$, and annual cycle $(\mathbf{g}-\mathbf{i})$ rice from 2015 to 2017. $\mathrm{FN}_{0}$ represents winter fallow without $\mathrm{N}$ application in rice seasons as a check, $\mathrm{MN}_{100}$ represents vetch cover cropping with $100 \mathrm{~kg} \mathrm{~N}^{-1}$ each rice season, $\mathrm{FN}_{100}$ represents winter fallow with $100 \mathrm{~kg} \mathrm{~N} \mathrm{ha}^{-1}$ each rice season, $\mathrm{MN}_{200}$ represents vetch cover cropping with $200 \mathrm{~kg} \mathrm{~N} \mathrm{ha}^{-1}$ each rice season, and $\mathrm{FN}_{200}$ represents winter fallow with $200 \mathrm{~kg} \mathrm{~N} \mathrm{ha}^{-1}$ each rice season. The data shown in the panels are averages of the three replications for individual treatments. Vertical bars represent the standard errors. Different lowercase letters represent the significant differences at $p<0.05$.

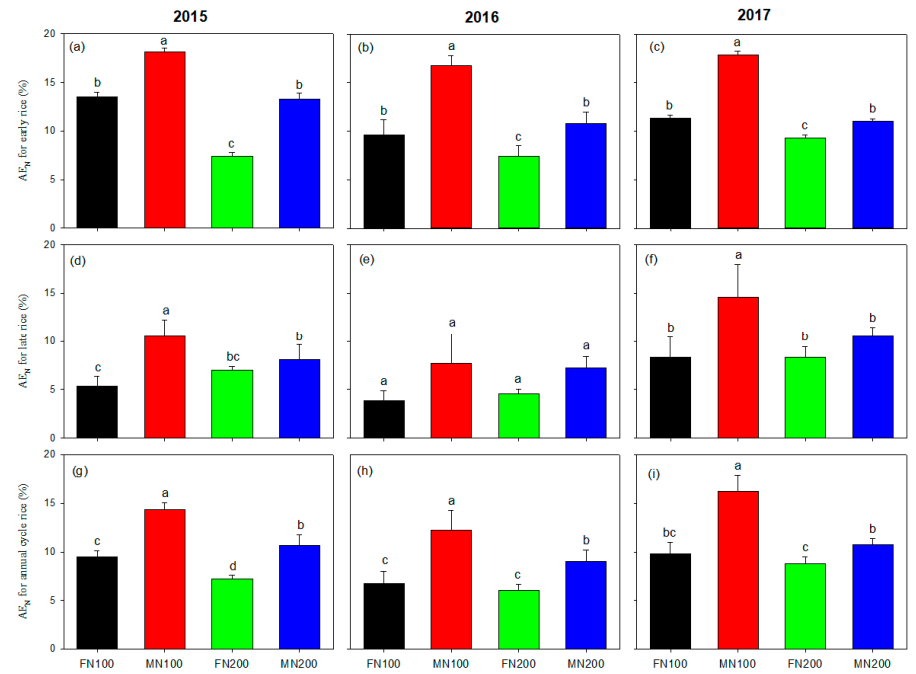

Figure 3. Agronomic $\mathrm{N}$ use efficiency for early $(\mathbf{a}-\mathbf{c})$, late $(\mathbf{d}-\mathbf{f})$, and annual cycle $(\mathbf{g}-\mathbf{i})$ rice from 2015 to 2017. $\mathrm{FN}_{0}$ represents winter fallow without $\mathrm{N}$ application in rice seasons as a check, $\mathrm{MN}_{100}$ represents vetch cover cropping with $100 \mathrm{~kg} \mathrm{~N}$ ha $^{-1}$ each rice season, $\mathrm{FN}_{100}$ represents winter fallow with $100 \mathrm{~kg} \mathrm{~N} \mathrm{ha}^{-1}$ each rice season, $\mathrm{MN}_{200}$ represents vetch cover cropping with $200 \mathrm{~kg} \mathrm{~N} \mathrm{ha}^{-1}$ each rice season, and $\mathrm{FN}_{200}$ represents winter fallow with $200 \mathrm{~kg} \mathrm{~N} \mathrm{ha}^{-1}$ each rice season. The data shown in the panels are averages of the three replications for individual treatments. Vertical bars represent the standard errors. Different lowercase letters represent the significant differences at $p<0.05$. 
Similar to $\mathrm{AE}_{\mathrm{N}}, \mathrm{RE}_{\mathrm{N}}$ was stimulated by vetch cover across the three experimental years (Figure 4). $\mathrm{RE}_{\mathrm{N}}$ values for early rice, late rice, and annual production were highest in $\mathrm{MN}_{100}$ plots $(24.6-41.8 \%$ for early rice, $19.6-32.8 \%$ for late rice, and $23.3-37.2 \%$ for annual cycle), followed by $\mathrm{MN}_{200}, \mathrm{FN}_{100}$, and $\mathrm{FN}_{200}$ (Figure 4). Under the same $\mathrm{N}$ dose, $\mathrm{MN}_{100}$ and $\mathrm{MN}_{200}$ also showed significantly greater $\mathrm{RE}_{\mathrm{N}}$ values than $\mathrm{FN}_{100}$ and $\mathrm{FN}_{200}$, respectively, for early rice, late rice, and annual cycle rice crops $(p<0.05)$.

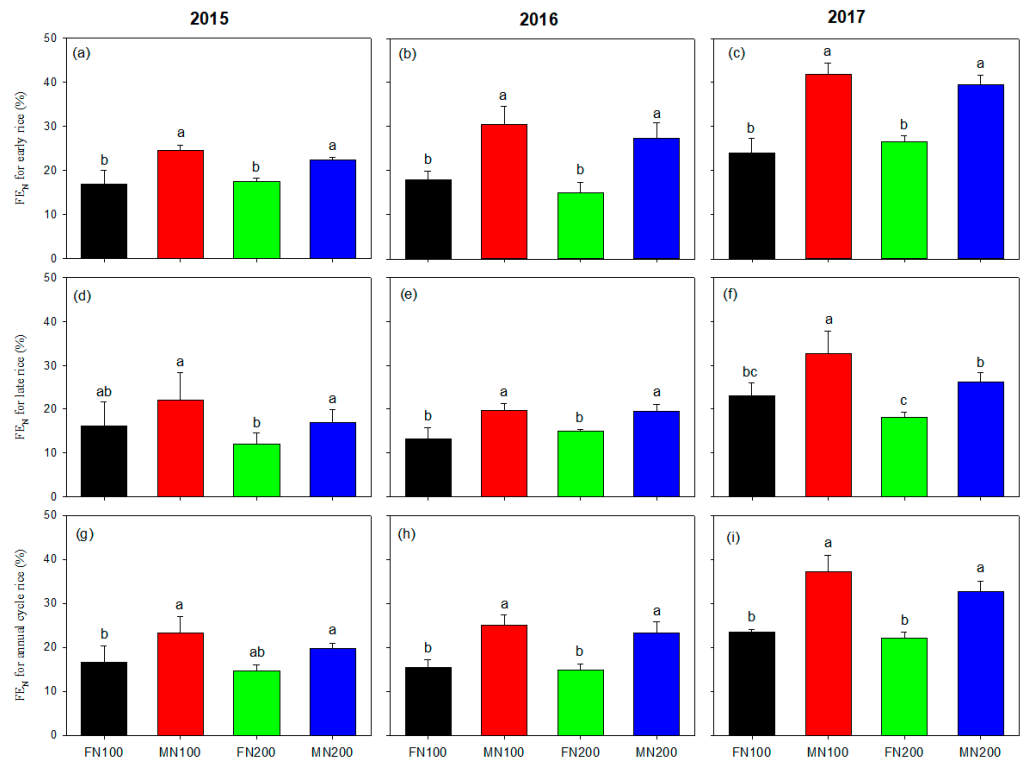

Figure 4. Fertilizer $\mathrm{N}$ recovery efficiency for early $(\mathbf{a}-\mathbf{c})$, late $(\mathbf{d}-\mathbf{f})$, and annual cycle $(\mathbf{g}-\mathbf{i})$ rice from 2015 to 2017. $\mathrm{FN}_{0}$ represents winter fallow without $\mathrm{N}$ application in rice seasons as a check, $\mathrm{MN}_{100}$ represents vetch cover cropping with $100 \mathrm{~kg} \mathrm{~N} \mathrm{ha}^{-1}$ each rice season, $\mathrm{FN}_{100}$ represents winter fallow with $100 \mathrm{~kg} \mathrm{~N} \mathrm{ha}^{-1}$ each rice season, $\mathrm{MN}_{200}$ represents vetch cover cropping with $200 \mathrm{~kg} \mathrm{~N} \mathrm{ha}^{-1}$ each rice season, and $\mathrm{FN}_{200}$ represents winter fallow with $200 \mathrm{~kg} \mathrm{~N} \mathrm{ha}^{-1}$ each rice season. The data shown in the panels are averages of the three replications for individual treatments. Vertical bars represent the standard errors. Different lowercase letters represent the significant differences at $p<0.05$.

\section{Discussion}

\subsection{Effect of Vetch Winter Cropping on Rice Grain Yield}

Effects of cover crops on the succeeding crop yields have been studied in various cropping systems around the world [9,15-17]. In most cases, leguminous cover crop species, such as alfalfa, red clover, and crimson clover, exhibit a positive effect on grain yield of subsequent corn or winter wheat in corn-cover crop and winter wheat-cover crop systems [18-20]. When it comes to rice, some studies reported grain yield increased following cover crops such as milk vetch, Sesbania rostrate, and Aeschynomene afraspera $[17,21,22]$. It is widely thought that the yield increase is the result of a better synchrony of $\mathrm{N}$ supply from the cover crop residues with main crop $\mathrm{N}$ demand. In addition to its ability to fix $\mathrm{N}$, leguminous cover crops are more likely to give a higher $\mathrm{N}$ return after incorporation, suggesting a possibility for replacing fertilizer $\mathrm{N}$ during main crop seasons.

In this study, the positive effect of milk vetch on the subsequent rice crops is in agreement with results from Yu et al. [23] and Zhu et al. [17], which showed a 5-10\% yield increase by including legumes such as bean or vetch in a rice-winter crop system. Similar positive effects on rice yield have been observed in multiple cropping systems such as rice-Azolla [24] and rice-fish [25]. In our study, milk vetch and subsequent early and late rice crops constituted a temporal multicropping system that resulted in enhanced rice crop yields. As reviewed by a number of reports $[9,12,15,16]$, biologically-fixed $\mathrm{N}$ from the leguminous cover crops is likely associated with the increase in the rice 
crop yields. Interestingly, we observed comparable rice yields for the treatments $\mathrm{MN}_{100}$ and $\mathrm{FN}_{200}$ (6.1 vs. $6.0 \mathrm{Mg} \mathrm{ha}^{-1}, 5.8$ vs. $6.0 \mathrm{Mg} \mathrm{ha}^{-1}$, and 11.9 vs. $12.0 \mathrm{Mg} \mathrm{ha}^{-1}$ for early rice, late rice, and total annual rice production, respectively). This implies a considerable potential for vetch in double-rice systems to reduce fertilizer $\mathrm{N}$ requirement while still meeting the goal of high rice grain yields [23]. The positive effect of milk vetch on yield was not limited to the early rice crop, but was also observed in the late rice crop. The possible explanation for this late rice effect is the greater $\mathrm{N}$ return from early rice straw in milk-vetch-treated plots (Figure 2).

The results of yield components analysis indicated that a greater rice plant panicle number was the only factor affected by milk vetch and fertilizer rate, rather than number of spikelets panicle ${ }^{-1}$, grain filling, and grain weight (Table 3). This implies that rice grain yield increase by milk vetch was a result of more vigorous growth of rice plants at or before the tillering stage [17].

\subsection{Effect of Vetch on Rice N Uptake and N Use Efficiency}

Another approach to managing the $\mathrm{N}$ economy of rice crops is to promote $\mathrm{N}$ retention by adding plant residues, such as straw, during the fallow period, but results from studies of the effects of straw application on the subsequent crop growth and $\mathrm{N}$ uptake are inconsistent. Some reported an insignificant increase or even a decrease in grain yield and $\mathrm{N}$ uptake after straw incorporation caused by short-term microbial immobilization associated with a high straw $\mathrm{C} / \mathrm{N}$ ratio [26,27]. Anaerobic decomposition of incorporated residues in a flooded paddy will release low-molecular-weight organic acids, some of which can inhibit root growth $[1,14]$. Others observed enhanced crop yield and $\mathrm{N}$ uptake with residue incorporation of a suitable $\mathrm{C} / \mathrm{N}$ ratio and when applied at the right time or in a right way [12,28,29]. In this study, the low $\mathrm{C} / \mathrm{N}$ ratio of the vetch biomass residue (20-25) and 10 days between vetch incorporation and rice transplanting allowed enough time for $\mathrm{N}$ release coinciding with early rice growth resulting in increased grain yield and $\mathrm{N}$ uptake. The increase in late rice grain yields and $\mathrm{N}$ uptake in vetch covering treatments could be explained by a higher $\mathrm{N}$ return from early rice straw biomass incorporation before late rice transplanting.

To better evaluate the sustainability of the vetch-double-rice system, it is important to consider options that have the potential both to improve rice production and to decrease chemical $\mathrm{N}$ demand. $A E_{N}$ and $R E_{N}$ are commonly used to measure $N$ cycling efficiency in ago-ecosystems $[14,16,28]$. As shown in Figure 3, the highest $\mathrm{AE}_{\mathrm{N}}$ values for early rice, late rice, and annual production were observed in vetch with $100 \mathrm{~kg} \mathrm{~N} \mathrm{ha}^{-1}$ (16.7-18.2\% for early rice, $7.7-14.6 \%$ for late rice, and $12.2-16.3 \%$ for annual cycle). The higher $\mathrm{AE}_{\mathrm{N}}$ in the vetch cropping treatments was the main explanation for the enhanced rice yields (Table 2). As reported by Bijay-Singh et al. [30] and $\mathrm{Xu}$ et al. [14], $\mathrm{AE}_{\mathrm{N}}$ was not significantly increased by $\mathrm{N}$ return from incorporated straw unless the incorporated residue or aboveground biomass was applied with a lower $\mathrm{N}$ rate. However, our findings suggested an increased $\mathrm{AE}_{\mathrm{N}}$ after the vetch winter crop and residue incorporation both under a moderate and high $\mathrm{N}$ rate. Yao et al. [31] also observed a higher $\mathrm{AE}_{\mathrm{N}}$ in rice with a green manure duckweed (Spirodela polyrhiza) at a total $\mathrm{N}$ application of $225 \mathrm{~kg} \mathrm{~N} \mathrm{ha}^{-1}$, which was even higher than in our study. The effects of cover crop/green manure or crop straw incorporation on the subsequent crop $\mathrm{AE}_{\mathrm{N}}$ may depend on the quality of the incorporated organic amendments, such as $\mathrm{C} / \mathrm{N}$ ratio [14], nitrogen release rate [10], and toxic material produced during residue decomposition [1,14].

Values for $\mathrm{RE}_{\mathrm{N}}$ in this three-year observation followed the range reported by other studies conducted in paddy soils $[12,28,29]$. The increase of $\mathrm{RE}_{\mathrm{N}}$ (Figure 4 ) in the vetch treatments was the result of a better synchronization between $\mathrm{N}$ supply and crop $\mathrm{N}$ demand, which was also observed in previous studies [31-33]. As reported by Zhu et al. [12] and Xie et al. [33] from a greenhouse pot trail, vetch combined with urea application resulted in a higher and more persistent soil inorganic $\mathrm{N}$ supply than urea applied alone. Furthermore, vetch cropping helped to increase soil microbial activities because vetch covering and incorporation may enhance vetch-microbe interaction by organic $\mathrm{C}$ and $\mathrm{N}$ input from vetch biomass and root rhizodeposition [23,32]. According to Yuan et al. [34], biological N fixation by vetch could supply 54.1 to $70.8 \mathrm{~kg} \mathrm{~N} \mathrm{ha}^{-1}$ to rice paddies in southern China. 
Reduced $\mathrm{N}$ loss may be another essential factor explaining the increased $\mathrm{N}$ recovery efficiency in association with vetch cropping, because a cover crop could retain soil native $\mathrm{N}$ which otherwise might be lost through leaching during winter fallow [23] and decrease $\mathrm{N}$ loss in the form of ammonia gas during rice growing seasons [31].

\section{Conclusions}

In an intensive double-cropped rice system in southern China, maintaining high grain yields and decreasing chemical $\mathrm{N}$ input is a double-win target for farmers and the environment. The present study indicated that winter cover cropping with leguminous vetch increased grain yields, $\mathrm{N}$ uptake, and $\mathrm{N}$ use efficiency of the subsequent early and late rice crops when compared with a winter fallow. The interaction between vetch residue incorporation and urea application significantly increased rice production while reducing chemical $\mathrm{N}$ input. Comparable grain yields (11.9 vs. $12.0 \mathrm{Mg} \mathrm{ha}^{-1}$ for annual rice cycle) between vetch with $100 \mathrm{~kg} \mathrm{~N} \mathrm{ha}^{-1}$ and fallow with $200 \mathrm{~kg} \mathrm{~N} \mathrm{ha}^{-1}$ suggested that winter cropping of vetch, combined with reduced $\mathrm{N}$ fertilizer, is a possible way to help reach the double-win target. The enhanced $\mathrm{N}$ use efficiency when vetch is supplied with $\mathrm{N}$ fertilizer would reduce $\mathrm{N}$ loss into the environment. These results show that winter covering of vetch helps to gain a more sustainable rice production system.

Author Contributions: B.Z., Z.Z., and Z.L. designed the experiments. J.N., L.Y., and H.X. performed the experiments. J.N., P.D., G.W.K., and B.A.H. analyzed the data. J.N. wrote the manuscript. All authors approved the submission.

Funding: This study was funded by the National Key Program of Research \& Development of China (2016YFD0300208-04), National Natural Science Foundation of China (No. 31870424, 31501274), Young Elite Scientists Sponsorship Program by CAST (No. YESS20160040), and China Scholarship Council (No. 201708420112).

Acknowledgments: Special thanks go to the anonymous reviewers for their constructive comments in improving this manuscript.

Conflicts of Interest: The authors declare no conflict of interest.

\section{References}

1. Peng, S.; Buresg, R.J.; Huang, J.; Zou, Y.; Zhong, X.; Wang, G.; Zhang, F. Strategies for overcoming low agronomic nitrogen use efficiency in irrigated rice systems in China. Field Crops Res. 2006, 96, 37-47. [CrossRef]

2. Ju, X.; Xing, G.; Chen, X.; Zhang, S.; Zhang, L.; Liu, X.; Cui, Z.; Yin, B.; Christie, P.; Zhu, Z.; et al. Reducing environmental risk by improving $\mathrm{N}$ management in intensive Chinese agricultural systems. Proc. Natl. Acad. Sci. USA 2009, 106, 3041-3046. [CrossRef] [PubMed]

3. Galloway, J.N.; Townsend, A.R.; Erisman, J.W.; Bekunda, M.; Cai, Z.; Freney, J.R.; Martinelli, L.A.; Seitzinger, S.P.; Sutton, M.A. Transformation of the nitrogen cycle: Recent trends, questions, and potential solutions. Science 2008, 320, 889-892. [CrossRef] [PubMed]

4. Liu, X.; Zhang, Y.; Han, W.; Tang, A.; Shen, J.; Cui, Z.; Vitousek, P.; Erisman, J.W.; Goulding, K.; Christie, P.; et al. Enhanced nitrogen deposition over China. Nature 2013, 494, 459-462. [CrossRef] [PubMed]

5. Geng, J.; Ma, Q.; Chen, J.; Zhang, M.; Li, C.; Yang, Y.; Yang, X.; Zhang, W.; Liu, Z. Effects of polymer coated urea and sulfur fertilization on yield, nitrogen use efficiency and leaf senescence of cotton. Field Crops Res. 2016, 187, 87-95. [CrossRef]

6. Chen, Y.; Peng, J.; Wang, J.; Fu, P.; Hou, Y.; Zhang, C.; Fahad, S.; Peng, S.; Cui, K.; Nie, L.; et al. Crop management based on multi-split topdressing enhances grain yield and nitrogen use efficiency in irrigated rice in China. Field Crops Res. 2015, 184, 50-57. [CrossRef]

7. Ramírez-García, J.; Carrillo, J.M.; Ruiz, M.; Alonso-Ayuso, M.; Quemada, M. Multicriteria decision analysis applied to cover crop species and cultivars selection. Field Crops Res. 2015, 175, 106-115.

8. Campiglia, E.; Mancinelli, R.; Radicetti, E.; Marinari, S. Legume cover crops and mulches: Effects on nitrate leaching and nitrogen input in a pepper crop (Capsicum annuum L.). Nutr. Cycl. Agroecosyst. 2011, 89, $399-412$. [CrossRef] 
9. Gabriel, J.L.; Quemada, M. Replacing bare fallow with cover crops in a maize cropping system: Yield, N uptake and fertilizer fate. Europ. J. Agron. 2011, 34, 133-143. [CrossRef]

10. Baijukya, F.P.; de Ridder, N.; Giller, K.E. Nitrogen release from decomposing residue of leguminous cover crops and their effect on maize yield on depleted soil of Bukoba District, Tanzania. Plant Soil 2006, 279, 77-93. [CrossRef]

11. Tribouillois, H.; Cohan, J.P.; Justes, E. Cover crop mixtures including legume produce ecosystem services of nitrate capture and green manuring: Assessment combining experimentation and modeling. Plant Soil 2016, 401, 347-364. [CrossRef]

12. Zhu, B.; Yi, L.; Hu, Y.; Zeng, Z.; Lin, C.; Tang, H.; Yang, G.; Xiao, X. Nitrogen released from incorporated ${ }^{15} \mathrm{~N}$-labelled Chinese milk vetch (Astragalus sinicus L.) residue and its dynamics in a double rice cropping system. Plant Soil 2014, 374, 331-344. [CrossRef]

13. Bremner, J.M.; Mulvaney, C.S. N-Total. In Methods of Soil Analysis, Part 2; Page, A.L., Miller, R.H., Keeney, D.R., Eds.; American Society of Agronomy: Madison, WI, USA, 1982; pp. 595-624.

14. Xu, Y.; Nie, L.; Buresh, R.; Huang, J.; Cui, K.; Xu, B.; Gong, W.; Peng, S. Agronomic performance of late-season rice under different tillage, straw, and nitrogen management. Field Crops Res. 2010, 115, 79-84. [CrossRef]

15. Constantin, J.; Mary, B.; Laurent, F.; Aubrion, G.; Fontaine, A.; Kerverillant, P.; Beaudoin, N. Effects of catch crops, no till and reduced nitrogen fertilization on nitrogen leaching and balance in three long-term experiments. Agric. Ecosyst. Environ. 2010, 135, 268-278. [CrossRef]

16. Deligios, P.A.; Tiloca, M.T.; Sulas, L.; Buffa, M.; Caraffini, S.; Doro, L.; Sanna, G.; Spanu, E.; Spissu, E.; Urracci, G.R.; et al. Stable nutrient flows in sustainable and alternative cropping systems of globe artichoke. Agron. Sustain. Dev. 2017, 37, 54-65. [CrossRef]

17. Zhu, B.; Yi, L.; Guo, L.; Chen, G.; Hu, Y.; Tang, H.; Xiao, X.; Yang, G.; Surya, N.A.; Zeng, Z. Performance of two winter cover crops and their impacts on soil properties and two subsequent rice crops in Dongting Lake Plain, Hunan, China. Soil Tillage Res. 2012, 124, 95-101. [CrossRef]

18. Claire, C.; John, D.L.; Bill, D.; Laura, L.V.E. Legume cover crop management on nitrogen dynamics and yield in grain corn systems. Field Crops Res. 2017, 201, 75-85.

19. Gaudin, A.; Janovicek, K.; Martin, R.C.; Deen, W. Approaches to optimizing nitrogen fertilization in a winter wheat-red clover (Trifolium pratense L.) relay cropping system. Field Crops Res. 2014, 155, 192-201. [CrossRef]

20. Katterings, Q.M.; Swink, S.N.; Duikr, S.W.; Czymmek, K.J.; Beegle, D.B.; Cox, W.J. Integrating cover crops for nitrogen management in corn systems on Northeastern U.S. dairies. Agron. J. 2015, 107, 1365-1376. [CrossRef]

21. Diekmann, K.K.; Ottow, J.C.G.; De Datta, S.K. Yield and nitrogen response of lowland rice (Oryza sativa L.) to Sebania rostrata and Aeschynomeme afraspera green manure in different marginally productive soils in Philippines. Biol. Fertil. Soils 1996, 21, 103-108. [CrossRef]

22. Lee, C.H.; Park, K.D.; Jung, K.Y.; Ali, M.A.; Lee, D.; Gutierrez, J.; Kim, P.J. Effects of Chinese milk vetch (Astragalus sinicus L.) as a green manure on rice productivity and methane emission in paddy soil. Agric. Ecosyst. Environ. 2010, 138, 343-347. [CrossRef]

23. Yu, Y.; Xue, L.; Yang, L. Winter legumes in rice crop rotations reduces nitrogen loss, and improves rice yield and soil nitrogen supply. Agron. Sustain. Dev. 2014, 34, 633-640. [CrossRef]

24. Xu, H.; Zhu, B.; Liu, J.; Li, D.; Yang, Y.; Zhang, K.; Jiang, Y.; Hu, Y.; Zeng, Z. Azolla planting reduces methane emission and nitrogen fertilizer application in double rice cropping system in southern China. Agron. Sustain. Dev. 2017, 37, 29-38. [CrossRef]

25. Xie, J.; Hu, L.; Tang, J.; Wu, X.; Li, N.; Yuan, Y.; Yang, H.; Zhang, J.; Luo, S.; Chen, X. Ecological mechanisms underlying the sustainability of the agricultural heritage rice-fish coculture system. Proc. Natl. Acad. Sci. USA 2011, 108, 1381-1387. [CrossRef] [PubMed]

26. Buresh, R.J.; Reddy, K.R.; van Kessel, C. Nitrogen transformations in submerged soils. In Nitrogen in Agricultural Systems, Agronomy Monograph 49; Schepers, J.S., Raun, W.R., Eds.; ASA, CSSA and SSSA: Madison, WI, USA, 2008; pp. 401-436.

27. Witt, C.; Cassman, K.G.; Olk, D.C.; Biker, U.; Liboon, S.P.; Sanson, M.I.; Ottow, J.C.G. Crop rotation and residue management effects on carbon sequestration, nitrogen cycling and productivity of irrigated rice systems. Plant Soil 2000, 225, 263-278. [CrossRef]

28. Asagi, N.; Ueno, H. Nitrogen dynamics in paddy soil applied with various ${ }^{15} \mathrm{~N}$-labelled green manures. Plant Soil 2009, 322, 251-262. [CrossRef] 
29. Ashraf, M.; Mahnood, T.; Azam, F.; Qureshi, R.M. Comparative effects of applying leguminous and non-leguminous green manures and inorganic $\mathrm{N}$ on biomass yield and nitrogen uptake in flooded rice (Oryza sativa L.). Biol. Fertil. Soils 2004, 40, 147-152. [CrossRef]

30. Shan, Y.H.; Johnson-Beebout, S.E.; Buresh, R.J. Crop residue management for lowland rice-based cropping systems in Asia. Adv. Agron. 2008, 98, 117-199.

31. Yao, Y.; Zhang, M.; Tian, Y.; Zhao, M.; Zhang, B.; Zhao, M.; Zeng, K.; Yin, B. Duckweed (Spirodela polyrhiza) as green manure for increasing yield and reducing nitrogen loss in rice production. Field Crops Res. 2017, 214, 273-282. [CrossRef]

32. Srivastava, J.K.; Chandra, H.; Kalra, S.J.S.; Mishra, P.; Khan, H.; Yadav, P. Plant-microbe interaction in aquatic system and their role in the management of water quality: A review. Appl. Water Sci. 2017, 7, 1079-1090. [CrossRef]

33. Xie, Z.; He, Y.; Tu, S.; Xu, C.; Liu, G.; Wang, H.; Cao, W.; Liu, H. Chinese Milk Vetch improves plant growth, development and ${ }^{15} \mathrm{~N}$ recovery in the rice-based rotation system of South China. Sci. Rep. 2017, 7, 3577. [CrossRef] [PubMed]

34. Yuan, M.; Liu, Q.; Zhang, S. Characteristics of nitrogen fixation of winter green manure in paddy soil in the Taihu Lake area. Chin. J. Soil Sci. 2010, 41, 1115-1119. (In Chinese)

(C) 2019 by the authors. Licensee MDPI, Basel, Switzerland. This article is an open access article distributed under the terms and conditions of the Creative Commons Attribution (CC BY) license (http://creativecommons.org/licenses/by/4.0/). 